\title{
Osallisuus ja hyvinvointi tiedeyhteisössä
}

\section{- tohtoriopiskelijoiden kokemuksia}

\author{
JENNI STUBB, KIRSI PYHÄLTÖ, TIINA SOINI, ANNA RAIJANUMMENMAA \& KIRSTI LONKA
}

\begin{abstract}
Kolmea yliopistoa koskeneessa tutkimuksessa selvitettiin sitä, minkälainen yhteys tiedeyhteisöllä ja siihen kuulumisen kokemuksella voi olla tohtoriopintojen pitkittymiseen tai keskeyttämiseen. Tiedeyhteisö näyttäytyy tohtoriopiskelijoille useimmiten mikrotason käytäntöyhteisönä, kuten tutkimusryhmänä tai yksikkönä ja lähityötovereina. Kokemus tiedeyhteisöstä saattaa muodostua niin voimaannuttavaksi kuin kuormittavaksikin. Koetun hyvinvoinnin ja opintojen etenemisen yhteys viittaa siihen, että tohtoriopiskelijan hyvinvointi ei ole ainoastaan väitöskirjaprosessin sivutuote, vaan yhteydessä myös tulokseen.
\end{abstract}

Tohtoriopiskelijat muodostavat valikoidun ja osaavan joukon, joka on valittu tohtorikoulutukseen useimmiten aiemman opintomenestyksen ja ansioituneen tutkimussuunnitelman perusteella. Tästä huolimatta monen tohtoriopiskelijan opinnot on vaarassa keskeytyä; suomalaisen tutkimuksen mukaan noin 45 prosenttia tohtoriopiskelijoista on harkinnut opintojensa keskeyttämistä (Pyhältö, Toom, Stubb \& Lonka 2009). Tämä on linjassa kansainvälisten jatko-opintojen keskeyttämistä koskevien tutkimustulosten kanssa, joiden mukaan 30-50 prosenttia tohtoriopiskelijoista keskeyttää opintonsa (esim. Bair \& Haworth 1999; Golde 2000; 2005; Oost \& Sonneveld 2004; Gardner 2008; Nettles \& Millet 2006).

Jatko-opintojen pitkittymisen, keskeyttämisen tai sen harkinnan taakse kätkeytyy hyvin monisyisiä tekijöitä. Selityksiä opintojen etenemisen ongelmiin on etsitty muun muassa motivaatioon liittyvistä tekijöistä (Hoskins \& Goldberg 2005), ohjauksen puutteista (Wright 2003), tieteelliseen kirjoittamiseen liittyvistä vaikeuksista (Lonka 2003) sekä perhetilanteisiin ja erilaisiin resurssitekijöihin liittyvistä seikoista (Hiltunen \& Pasanen 2005). Näiden tekijöiden lisäksi väitöskirjatutkimusprosessin ongelmien on todettu liittyvän usein tohtoriopiskelijan ja hänen tiedeyhteisönsä väliseen suhteeseen (Appel \& Dahlgren 2003; Bair \& Haworth 1999; Gardner 2007; Golde, 2005; Pyhältö, Stubb \& Lonka 2009.) Hiltunen ja Pasanen ovat raportoineet suomalaisten tohtoriopiskelijoiden kokemuksia ja arvioita tohtorikoulutuksesta vuonna 2006. Kuitenkin siitä, miten tohtoriopiskelijat oman tiedeyhteisönsä kokevat ja millainen yhteys näillä kokemuksilla on opintojen pitkittymiseen ja keskeyttämisriskiin tiedetään edelleen melko vähän. Tässä artikkelissa keskitymme tarkastelemaan tiedeyhteisön merkitystä jatko-opiskelussa tohtoriopiskelijoiden kokemusten valossa.

\section{Oppimista ja hyvinvointia tiedeyhteisössä}

Yhteisöstä ja yhteisöllisyydestä on tullut yleistyvä tapa puhua tohtorikoulutuksen kehittämisestä. Se, mitä tiedeyhteisöllä kulloinkin tarkoitetaan, ei kuitenkaan ole itsestään selvää. Tiedeyhteisön käsite saa erilaisia sisältöjä riippuen siitä, minkä toimintakontekstin, ilmiön tai tieteenalan näkökulmasta yhteisöä lähestytään ja tutkitaan (Luker \& Orr 1992). Tiedeyhteisöä voidaankin tarkastella systeemisenä kokonaisuutena (Becher 1994; Nummenmaa \& Pyhältö 2008). Laajimmillaan tiedeyhteisöllä voidaan viitata tieteenalaan tai kansainvä- 
liseen tutkijayhteisöön, jonka toimintaan opiskelija saattaa osallistua esimerkiksi artikkeleita kirjoittamalla tai pitämällä esitelmän kansainvälisessä konferenssissa. Tiedeyhteisö voi näyttäytyä myös institutionaalisen rakenteen kautta, kuten yliopistona, tiedekuntana tai laitoksena. Tohtorikoulutuksen arjessa tiedeyhteisö näyttäytyy tohtoriopiskelijalle useimmiten mikrotason käytäntöyhteisönä, kuten tutkimusryhmänä, lähityötovereina, seminaarina tai yksikkönä. Se, mitä tiedeyhteisö tohtoriopiskelijalle ensisijassa merkitsee ja millaiseksi opiskelija oman roolinsa siinä hahmottaa, säätelee hänen osallisuutensa laatua ja edelleen sitä, minkälaista tieteellistä asiantuntijuutta hän oppii - esimerkiksi sitä millaista tutkijaidentiteettiä tohtoriopiskelija itselleen rakentaa (McAlpine \& Amundsen 2009).

Tohtorikoulutuksen tavoitteeksi on määritelty uuden tutkimustiedon tuottaminen ja tieteellisen asiantuntijuuden oppiminen (Yliopistolaki 645/ 1997). Siihen saavutetaanko nämä tavoitteet, vaikuttavat monet tekijät aina rekrytoinnista arviointiin (Nummenmaa \& Pyhältö 2008). Jatkokoulutuksen pedagogiikka realisoituu kuitenkin ensisijassa mikrotasolla tohtorikoulutuksen arjen käytännöissä ja ohjauksessa. Näin ollen tiedeyhteisö muodostaa tohtoriopiskelijalle keskeisen väitöskirjatutkimuksen tekemisen ja tieteellisen asiantuntijuuden oppimisympäristön, joka sisältää niin fyysisen ympäristön kuin ohjaus-, tieto- ja arviointikäytännöt (Gardner 2007; Becher \& Trowler 2001). Erityisesti sen tiedeyhteisön normit, käytänteet ja toimintatavat, jonka osana tohtoriopiskelija opintojaan tekee,vaikuttavat siihen, millaiseksi tämän opiskelupolku rakentuu. Käytännössä tiedeyhteisön vaikutus ulottuu aina tutkimusaiheen valinnasta siihen, miten ohjaus on järjestetty. Esimerkiksi monilla luonnontieteellisillä ja teknisillä aloilla tutkimusta tehdään pääasiallisesti tutkimusprojekteissa, jolloin ohjaus rakentuu osaksi tutkimusryhmän toimintaa. (Vehviläinen, Pyhältö, Lindblom-Ylänne, Löftström, Nevgi \& Kaartinen-Koutaniemi 2009). Tällaiset tiedeyhteisön käytänteet perustuvat akateemisiin traditioihin ja eri tieteenaloille tyypillisiin tiedekulttuureihin, joissa edelleen heijastuvat alalle tyypilliset tieto- ja oppimiskäsitykset (Biglan 1973; Ylijoki 1998). Tieteenalojen lokeroiminen tiedekulttuurien perusteella antaa kuitenkin tohtorinkoulutuksen todellisuudesta yksinkertaistetun kuvan, sillä jo yhden tieteenalan sisällä tehdään tutkimusta hyvin erilaisista lähtökodista.
Tieteellisen asiantuntijuuden oppimista ja tutkijaksi kasvamista voidaan tarkastella osallistumisena tiedeyhteisön muodostamaan käytäntöyhteisöön (community of practise) (Wenger 1999). Tieteelliseksi asiantuntijaksi kehittymistä on kuvattu asteittain etenevänä osallisuuden lisääntymisenä tiedeyhteisössä, jossa tohtoriopiskelija siirtyy tiedeyhteisön reuna-alueilta kohti yhteisön keskiötä ja täysivaltaista osallisuutta (Delamont, Atkinson \& Parry 2000; Golde 2005; Hasrati 2005; McAlpine, Jazvac-Martek \& Hopwood 2008; Wright 2003). Tiedeyhteisön arvot, normit ja käytänteet voivat kuitenkin sekä tukea että estää tohtoriopiskelijan osallisuutta. Parhaimmillaan tiedeyhteisö muodostaa oppimisympäristön, jossa tiedeyhteisön varttuneemmat jäsenet pyrkivät tietoisesti ja tavoitteellisesti tukemaan opiskelijan osallisuutta esimerkiksi yhteisöllisiä, tutkivia ja aktivoivia työmenetelmiä hyödyntämällä (Lonka 2003; Styles \& Radloff 2001). Näin rakentuva, opiskelijan ja hänen oppimisympäristönsä välinen rakentava jännite (lisää rakentavasta jännitteestä Vermunt \& Verloop 1999) auttaa opiskelijaa omien rajojensa ylittämisessä ja vastaamaan kohtaamiinsa ongelmiin. Pahimmassa tapauksessa hyvin autoritääriset ohjauskäytännöt tai kokonaan vaille tukea jääminen voivat puolestaan johtaa opiskelijan syrjäytymiseen tohtorikoulutuksesta. On myös hyvä huomata, että tieteelliseksi asiantuntijaksi kehittymisessä ei ole kyse ainoastaan tohtoriopiskelijan sopeutumisesta tiedeyhteisön valitseviin toimintatapoihin. Opiskelijat ovat myös olemassa olevien käytäntöjen uudistumisen ja kyseenalaistamisen keskeinen käyttövoima.

Tiedeyhteisön käytännöissä rakentuu paitsi oppimista, myös hyvinvointia ja pahoinvointia. Monet tohtoriopiskelijoiden hyvinvointia koskevat kansainväliset tutkimukset ovat osoittaneet, että uuden tiedon ja oivaltamisen ilon lisäksi tohtorikoulutuksen arjessa ilmenee uupumista ja pahoinvointia: opiskelijat kokevat melko paljon ahdistusta, masennusta ja stressiä opiskelunsa aikana (esim. Toews, Lockyer, Dobson \& Brownell 1993; Bauer, Abric, Drozda-Senkowska, Lemaire, Lorenzi-Cioldi, Niedenthal, Santioso, Schadron, Steiner \& Yzerbyt 2003). Hyvinvoinnin rakentuminen tiedeyhteisössä (Stubb, Pyhältö, Soini \& Lonka 2009) voidaan hahmottaa osallisuuden, osaamisen kokemuksen ja autonomisuuden (Ryan \& Deci 2000; 2001; 2008) mahdollistavana oppimisprosessina. Hyvinvoinnin rakentumista väitöskirjaprosessissa voidaan tarkastella positiivisina 
tai negatiivisina oppimisen kehinä, jossa myönteiset tai kielteiset oppimisympäristöön sijoittuvat arkiset kokemukset johtavat parhaimmillaan tohtoriopiskelijan voimautumiseen tieteentekijänä ja pahimmillaan taas uupumiseen ja jopa opintojen keskeyttämiseen. Hyvinvoinnin rakentumisessa on kyse aktiivisesta, yhteisöllisestä ja tilannesidonnaisesta prosessista (Pyhältö, Soini \& Pietarinen painossa), jossa tohtoriopiskelijoiden ja heidän ympäristönsä välinen suhde, esimerkiksi toiminnan kohde ja osallistumisen muodot, jatkuvasti muuttuvat ja uudelleen määrittyvät. Tärkeää kuitenkin on, että tiedeyhteisö tarjoaa tohtoriopiskelijalle riittävän haastavan, rohkaisevan ja hyväntahtoisen oppimisympäristön, jossa myös epäonnistuminen ja uudelleen yrittäminen on mahdollista (Pyhältö \& Soini 2008).

\section{TUTKIMUKSEN TOTEUTUS}

\section{Tutkimuksen tavoite}

Tässä kuvatun tutkimuksen tavoitteena on tarkastella tohtoriopiskelijoiden kokemaa osallisuutta ja hyvinvointia tiedeyhteisössä. Lisäksi tavoitteena on selvittää, miten nämä kokemukset ovat yhteydessä sekä toisiinsa että muihin tekijöihin, kuten väitöskirjaprosessin etenemiseen, sukupuoleen, yliopistoon, tieteenalaan ja tutkimusryhmässä työskentelyyn. Tutkimus on osa laajempaa kolmen yliopiston yhdessä toteuttamaa kansallista tieteelliseen jatkokoulutukseen liittyvää tutkimushanketta, jonka tavoitteena on selvittää keskeisiä säätelijöitä ja ehtoja onnistuneelle väitöskirjaprosessille, ohjausvuorovaikutusta sekä sitä, minkälaisina akateemisen asiantuntijuuden oppimisympäristöinä tutkimusryhmät toimivat. Tässä artikkelissa keskitymme seuraavien kysymysten tarkasteluun:

1. Miten tohtoriopiskelijat kokevat oman osallisuutensa tiedeyhteisössä?

2. Miten tohtoriopiskelijat kokevat oman hyvinvointinsa tiedeyhteisössä?

3. Miten koettu osallisuus ja hyvinvointi ovat yhteydessä toisiinsa?

4. Miten koettu osallisuus ja hyvinvointi ovat yhteydessä opintojen etenemiseen keskeyttämisen harkinnan ja opintojen pitkittymisen valossa?

5. Miten erilaiset taustamuuttujat (yliopisto, tieteenala, sukupuoli ja tutkimusryhmässä työskentely) tekemiselle ovat yhteydessä kokemuksiin?

\section{Aineistonkeruu}

Tutkimuksen aineisto kerättiin vuosina 2006-2008 kyselylomakkeella ja siihen vastasi yhteensä 1006 tohtoriopiskelijaa Helsingin ( $\mathrm{n}=669)$, Tampereen $(n=176)$ ja Oulun yliopistoista $(n=161)$. Yliopistot valittiin sen perusteella, että ne edustavat maantieteellisesti hyvin suomalaisia yliopistoja ja ovat toisaalta kaikki suuria monialayliopistoja. Kysely lähetettiin Helsingissä kaikille lääketieteellisen, humanistisen ja käyttäytymistieteellisen tiedekunnan (pois lukien kotitalous- ja käsityötieteet sekä logopedia) tohtoriopiskelijoille. Oulun yliopistossa kysely lähetettiin kaikille tohtoriopiskelijoille ja Tampereen yliopistossa läsnä olevaksi ilmoittautuneille informaatiotieteiden, yhteiskuntatieteiden ja kasvatustieteiden tiedekunnan sekä terveystieteiden laitoksen tohtoriopiskelijoille. Opiskelijoiden yhteystiedot saatiin yliopistojen opintorekisteristä. Helsingin yliopistosta enemmistö aineistosta kerättiin postikyselyllä. Osalle opiskelijoista kysely lähetettiin sähköpostitse. Oulun ja Tampereen yliopistossa kaikki kyselyt tehtiin sähköisesti. Tohtoriopiskelijat, joiden äidinkieli oli jokin muu kuin suomi, saivat englanninkielisen kyselyn. Kokonaisvastausprosentti oli Helsingin yliopiston osalta 38,4 prosenttia ja Tampereen yliopiston osalta 25 prosenttia. Oulun yliopiston osalta tarkkaa vastausprosenttia on vaikea laskea opintorekisteriteknisistä syistä johtuen; tiedekunnasta riippuen n. 20-40 prosenttia jatko-opiskelijoista rekisteröityneistä ei aktiivisesti tee väitöskirjaa. Kyselyä ei myöskään puutteellisten osoitetietojen vuoksi saatu lähetettyä kaikille rekisteröityneille opiskelijoille. On todennäköistä, että Helsingin ja Tampereen yliopistojen vastausprosentit jäivät melko alhaisiksi samoista syistä.

Kysely koostui avoimista kysymyksistä, Likerttyyppisistä väittämistä ja taustamuuttujista. Kyselylomakkeen strukturoidut väittämät muokattiin MED NORD - kyselyn pohjalta tohtorinkoulutuskontekstiin sopiviksi (Lonka, Sharafi, Karlgren, Masiello, Nieminen, Birgegård, \& Josephson 2008). Tässä artikkelissa keskitytään avoimeen kysymykseen, jossa kysyttiin tohtoriopiskelijan kokemusta omasta roolistaan tiedeyhteisössä sekä väittämiin, jotka mittasivat opintojen etenemistä. Opintojen etenemistä mitattiin kysymällä, oliko opiskelija jossain vaiheessa omaa prosessiaan harkinnut opintojensa keskeyttämistä. Tämän lisäksi opintojen etenemistä tarkasteltiin opintojen pitkittymisellä. Se muodostettiin muuttujista, joissa kysyt- 
tiin opintojen aloitusvuotta ja opiskelijan omaa arviota valmistumisvuodesta. Opintojen pitkittymisen rajana pidettiin 10 vuotta, joka on 2,5-kertainen suhteessa opetusministeriön asettamaan neljän vuoden tavoitteeseen. Lisäksi tarkasteltiin sitä, olivatko kokemukset yhteydessä yliopistoon, tieteenalaan, sukupuoleen ja siihen tekivätkö opiskelijat tutkimustaan yksin vai ryhmässä.

\section{Tohtoriopiskelijat tutkimusjoukkona}

Vastaajista 70 prosenttia oli naisia ja 30 miehiä. Suhteellisesti suurin osuus naisvastaajia oli Helsingin yliopistossa ja pienin Oulun yliopistossa. Tohtoriopiskelijoiden keski-ikä oli 38 vuotta (mediaani 35). Nuorimmat vastaajat olivat Oulun yliopistosta ja vanhimmat Tampereen yliopistosta. (Taulukko 1.) Kuten LIITTEISTÄ 1 ja 2 käy ilmi, yliopistojen vuoden 2008 tilastojen perusteella voidaan todeta, että tutkimuksen tavoitettu otos vastaa sukupuolijakauman ja iän osalta suomalaisten tohtoriopiskelijoiden perusjoukkoa melko hyvin. Pääosa tohtoriopiskelijoista (78\% )raportoi tekevänsä väitöskirjatutkimustaan yksin. Noin neljännes opiskelijoista (22\%) teki tutkimusta ainakin osittain tutkimusryhmässä ja 11 prosnettia heistä ensisijaisesti osana tutkimusryhmää. Kyselyyn vastanneet tohtoriopiskelijat olivat eri vaiheissa omaa väitöskirjaprosessiaan, kuitenkin niin, että enemmistö opiskelijoista (59 \%) oli oman arvionsa mukaan prosessinsa viimeisessä kolmanneksessa.

Tieteenalat, joita tohtoriopiskelijat edustivat luokiteltiin seitsemään luokkaan mukaillen Tilastokeskuksen tieteenalaluokitusta: humanistiset tieteet (39\%), yhteiskuntatieteet ja kauppatieteet (10\%), käyttäytymistieteet (22\%), lääke- ja terveystiede (19\%) sekä matemaattis-luonnontieteelliset ja teknistieteelliset alat (10\%).

\section{Analyysi}

Avoimen kysymyksen vastaukset analysoitiin laadullisella sisällönanalyysilla niin, että analyysia ohjasi tutkittavaan ilmiöön liittyvän teoreettisen esiymmärryksen ja aineistosta nousevien seikkojen vuoropuhelu. Analyysi eteni useiden aineistonlukukertojen kautta lopullisten luokkien muodostumiseen. Aineistoesimerkit avoimista vastauksista on valittu sen perusteella, että ne edustavat kyseisen luokan yleistä vastaustyyppiä hyvin.

Ensimmäisessä analyysissa opiskelijoiden vastauksia avoimeen kysymykseen tarkasteltiin suhteessa siihen, minkälaisena he kuvasivat osallisuuttaan tiedeyhteisöön. Opiskelijoiden kuvauksia omasta roolistaan analysoitiin sen mukaan kertoivatko he kuuluvansa omaan tiedeyhteisöönsä.

TAULUKKO 1: Sukupuolijakaumat, keski-ikä ja iän mediaani tutkimuskonteksteittain

$\begin{array}{llll}\text { Naiset } \% & \text { Miehet } \quad \% \quad \text { Ikä (ka/med.) }\end{array}$

\begin{tabular}{lrrrrr}
\hline Helsinki & 496 & 75 & 169 & 25 & $41 / 35$ \\
Humanistinen tiedekunta & 244 & 70 & 102 & 30 & $38(35)$ \\
Käyttäytymistieteellinen & 123 & 79 & 33 & 21 & $41(39)$ \\
Lääketieteellinen & 129 & 80 & 33 & 20 & $38(34)$ \\
& & & & & \\
Tampere & $\mathbf{1 1 8}$ & $\mathbf{6 7}$ & $\mathbf{5 8}$ & $\mathbf{3 3}$ & $\mathbf{4 0 / 3 8}$ \\
$\quad$ Informaatiotieteiden tdk & 24 & 51 & 23 & 49 & $38 / 37$ \\
$\quad$ Yhteiskuntatieteiden tdk & 56 & 72 & 22 & 28 & $39 / 37$ \\
Kasvatustieteiden tdk & 22 & 67 & 11 & 33 & $43 / 46$ \\
Terveystieteen laitos & 14 & 93 & 1 & 7 & $39 / 35$ \\
& & & & & \\
\hline Oulu & $\mathbf{9 0}$ & $\mathbf{5 6}$ & $\mathbf{7 1}$ & $\mathbf{4 4}$ & $\mathbf{3 6 / 3 2}$ \\
$\quad$ Humanistinen & 27 & 73 & 10 & 27 & $31 / 31$ \\
Kasvatustieteet & 2 & 50 & 2 & 50 & $44 / 43$ \\
$\quad$ Luonnontieteellinen & 12 & 63 & 7 & 37 & $39 / 40$ \\
Lääketieteellinen & 8 & 80 & 2 & 20 & $37 / 35$ \\
Kauppatieteet & 11 & 61 & 7 & 39 & $37 / 33$ \\
Teknilliset tieteet & 18 & 34 & 35 & 66 & $34 / 31$ \\
Yhteensä & 704 & $\mathbf{7 0}$ & 298 & $\mathbf{3 0}$ & $\mathbf{3 8} / \mathbf{3 5}$
\end{tabular}


Analyysi johti kolmeen pääluokkaan: (a) kokemus omasta roolista tiedeyhteisön jäsenenä, (b) kokemus itsestä ulkopuolisena ja (c) jäsentymätön tai ristiriitainen kokemus omasta roolista. Luokat perustuivat aineiston pohjalta tehtyyn havaintoon, jonka mukaan opiskelijoiden kokemukset omasta roolistaan erosivat toisistaan hyvin paljon. Osa opiskelijoista piti itseään yhteisön jäsenenä ja koki oman roolinsa hyvin selkeänä, kun taas osa opiskelijoista raportoi hyvin selkeästi kokevansa itsensä täysin ulkopuoliseksi suhteessa tiedeyhteisöön. Vastauksissa oli myös erotettavissa joukko vastauksia, joissa heijastui kokemus siitä, että oma rooli ei ollut aivan selvä. Osaksi tiedeyhteisöä itsensä kokevat kuvasivat rooliaan tyypillisesti osana laajempaa yhteisöä, asiantuntijaksi kehittyvänä opiskelijana tai jo asiantuntijana tai yhteisön hyödyn näkökulmasta, esimerkiksi halpana työvoimana.

Toisessa, riippumattomassa analyysissa, vastauksia avoimeen kysymykseen tarkasteltiin sen valossa, miten tohtoriopiskelijat kuvasivat omaa hyvinvointiaan suhteessa tiedeyhteisöön. Aineiston perusteella voitiin todeta, että opiskelijoiden kokemukset olivat melko polarisoituneita; osa vastauksista heijasti selkeästi positiivisia kokemuksia kun taas osassa vastauksia omaa suhdettaan tiedeyhteisöön kuvattiin hyvin negatiivisella tavalla. Vastaukset analysoitiin sen mukaan kuvasivatko tohtoriopiskelijat suhdettaan tiedeyhteisöön a) voimauttavana vai b) kuormittavana. Voimautumisen kuvauksille tyypillistä oli inspiraation ja tuen saamisen kokemukset sekä tunne siitä, että oma työ oli merkityksellistä tiedeyhteisön näkökulmasta. Lisäksi tähän luokkaan kuuluvissa vastauksissa opiskelijat kuvasivat rooliaan usein positiivisesti ja/tai ilmaisivat olevansa tyytyväisiä siihen. Niille vastauksille, joista kuvastui tiedeyhteisön kokeminen kuormittavan tekijänä oli tyypillistä itsensä ulkopuoliseksi ja arvottamaksi näkeminen sekä tiedeyhteisössä toimimisen näkeminen rasittavana. Kuormitustekijänä koetun kokemuksen kriteerinä pidettiin myös sitä, että henkilö oli kuvannut omaa rooliaan negatiiviseen sävyyn ja/ tai ilmaissut olevansa siihen tyytymätön.

Laadullista analyysia seurasi tilastollisen analyysin vaihe, jossa tohtoriopiskelijoiden raportoimaa osallisuuden ja hyvinvoinnin kokemusta analysoitiin sekä suhteessa toisiinsa että suhteessa väitöskirjatyön etenemiseen (keskeyttämisen harkinta ja opintojen pitkittyminen) käyttäen apuna ${ }^{2}$ testiä (merkitsevyystaso $\mathrm{p}<.05$ ). Samalla menetel- mällä analysoitiin myös sitä, miten eri taustamuuttujat olivat yhteydessä tohtoriopiskelijoiden kokemuksiin.

\section{Tutkimustulokset}

\section{Tohtoriopiskelijoiden kokemus omasta osallisuudestaan tiedeyhteisössä}

Tiedeyhteisö merkitsi tohtoriopiskelijoille merkitsi opiskelijoille eri asioita. Osalle tiedeyhteisö tarkoitti omaa tutkimusryhmää, jatko-opintoseminaaria tai ainelaitosta, kun taas toisille tiedeyhteisö hahmottui laajemmin kokonaisena tieteenalana ja sen edustajina. Myös tohtoriopiskelijoiden kokemukset omasta itsestään tiedeyhteisön jäseninä vaihtelivat merkittävästi osallisuuden kokemuksista aina kokonaisvaltaisen ulkopuolisuuden kokemuksiin. Osalle tohtoriopiskelijoita oma rooli oli vielä hahmoton tai jäsentymätön ja osa koki roolinsa jollakin tavalla ristiriitaiseksi.

Enemmistö (54\%) tohtoriopiskelijoista raportoi kokevansa itsensä osaksi tiedeyhteisöä, vaikkakin kokemuksen laatu vaihteli merkittävästi. Tohtoriopiskelijat, jotka näkivät itsensä selkeästi osana tiedeyhteisöä, kuvasivat rooliaan usein opiskelijan, junioritutkijan tai joissain tapauksissa jo oman alansa asiantuntijan roolina. He raportoivat kokevansa, että heillä oli oman tutkimuksensa kautta mahdollisuus olla mukana kehittämässä omaa tieteenalaansa. Monet tohtoriopiskelijoista kuvasivat olevansa matkalla opiskelijan roolista kohti täysivaltaisempaa tutkijaa ja tiedeyhteisön jäsentä.

"Välillä koen olevani vasta 'opiskelija' tieteentekijäksi, välillä koen jo olevani alan asiantuntija. Koen kuitenkin työni olevan merkityksellistä ja tärkeää tiedeyhteisössäni."

Osa tiedeyhteisöä 1

\begin{abstract}
"Jossain määrin koen itseni vielä opiskelijaksi, mutta samalla olen ottamassa ensiaskeleita itsenäisenä tutkijana. Tarkoituksenani on osallistua jatkossa entistä enemmän konferensseihin, jotta löytäisin kontakteja, jotka mielestäni ovat erittäin tärkeitä jatko-opiskelijan integroitumisen kannalta."

Osa tiedeyhteisöä 2
\end{abstract}

Samanaikaisesti toiset tohtoriopiskelijat kokivat oman roolinsa merkityksellisyyden laitoksen 
saaman hyödyn näkökulmasta: halpana työvoimana tai tulosjohtamisen mittarina. Nämä opiskelijat hahmottivat tehtäväkseen käytännön tutkimuksen tekemisen pienellä rahalla ja nopean valmistumisen, jotta laitos saisi toteutuneesta tutkinnosta taloudellisen hyödyn. He kuvasivat tilanteensa epäkiitollisena, koska heidän aikansa meni muiden ihmisten töiden tekemiseen eikä oman väitöskirjatutkimuksen edistämiseen.

"Roolini on äärimmäisen tärkeä, koska laitoksen pitää tuottaa tohtoreita saadakseen rahoitusta ja vahvemman statuksen."

Osa tiedeyhteisöä 3

"Maisteri on pohjasakkaa, jonka tutkinto ei ole minkään arvoinen. Valkokaulusorja, jonka tehtävä on pienen pienellä palkalla myydä sielunsa ja tehtävä ympäripyöreää päivää ja lopulta palaa loppuun, kun samaan aikaan johtaja kerää rahat ja kunnian."

Osa tiedeyhteisöä 4

Noin kolmannes (29\%) tohtoriopiskelijoista kuitenkin näki itsensä tiedeyhteisöstä täysin ulkopuolisena. He toivat vastauksissaan esiin, etteivät he kokeneet kuuluvansa tiedeyhteisöön tai etteivät kyenneet näkemään tiedeyhteisön olemassaoloa. Osassa vastauksia ulkopuolisuuden syitä pohdittiin muun muassa osa-aikaisuuden, tutkimusaiheen luonteen ja tutkimusryhmän puutteen näkökulmasta. Monet itsensä ulkopuoliseksi kokevat tohtoriopiskelijat myös raportoivat kaipaavansa yhteyttä tiedeyhteisöön, koska kokivat tämän tärkeäksi oman oppimisprosessin ja työn edistymisen kannalta. Moni kuvasi tieteelliselle työlle oleellisen osan puuttuvan ulkopuolisuuden kokemuksen vuoksi.

"Olen aika ulkopuolinen osittain aiheeni vuoksi ja osittain sen takia, että en tällä hetkellä tee väitöskirjaa kokopäiväisesti”" Ulkopuolinen 1

"Tällä hetkellä täysin ulkopuolisena: käyn säännöllisesti seminaareissa, mutta muita kontakteja ei juuri ole. Ohjaajaan olen yhteyksissä virallisissa asioissa, mutta kaipaisin 'epävirallisempaa' keskusteluyhteyttä jonkun samoista kysymyksistä kiinnostuneen kanssa" Ulkopuolinen 2
Noin viidennes (17\%) näki oman roolinsa tiedeyhteisössä jäsentymättömäksi tai ristiriitaiseksi. Jäsentymättömyys kuvastui vaikeuksina hahmottaa tai kuvata omaa roolia ja se liitettiin monissa vastauksissa väitöskirjaprosessin alkuvaiheessa olemiseen. Ristiriitaisuus puolestaan näkyi siinä, että tietystä näkökulmasta katsottuna rooli koettiin mielekkääksi, kun taas toisesta näkökulmasta katsottuna ei. Tyypillistä tämänkaltaisille vastauksille oli koherenssin puute.

"Omassa tutkimusryhmässämme koen olevani tärkeä ja arvostettu työntekijä ja olen ehdottomasti osa sitä yhteisöä. Laajemmin yliopistolla roolia on vaikeampi hahmottaa. toisaalta tuntuu, että on sielläkin 'arvokas', mutta toisaalta kuitenkaan apurahatutkijaan kukaan ei halua sijoittaa mitään. Halutaan siis tulosta, mutta sitä varten ei panosteta muuten. Siinä arvostuksen tunne vähän kärsii." Jäsentymätön/Ristiriitainen 1

"Vaihtelee paljon. Joskus pystyy kontribuoimaan jotain järjellistä ja osallistumaan ns. akateemiseen toimintaan. Joskus on pelkkänä taakkana ja joutuu häpeämään itseään."

Jäsentymätön/Ristiriitainen 2

\section{Koettu hyvinvointi tiedeyhteisössä}

Myös tohtoriopiskelijoiden kokemukset omasta hyvinvoinnistaan suhteessa tiedeyhteisöön olivat hyvin erilaisia. Kokemukset vaihtelivat aina voimauttavista ja inspiroivista kokemuksista kuormittumisen ja uupumuksen kokemuksiin. Hieman alle puolet opiskelijoista (44\%) koki tiedeyhteisönsä inspiraation, oivallusten ja tuen lähteeksi. Nämä tohtoriopiskelijat raportoivat omaa kokemustaan tiedeyhteisöstä hyvin positiivisessa valossa. Heidän kuvauksistaan kävi ilmi, että he kokivat tiedeyhteisön rakentavalla tavalla tukevan omaa väitöskirjaprosessiaan. Voimauttava kokemus yhdistettiin vastauksissa hyvin erilaisiin tekijöihin, kuten kontribuution, osallisuuden, merkityksellisyyden ja arvokkuuden kokemukseen, tutkijaidentiteetin vahvistumiseen, tutkimustyön kokemiseen luovana ja itsenäisenä työnä sekä hyvään tukeen oppimiselle ja tutkimuksen tekemiselle.

"Vastuullisena ja vaativana, toisaalta turvallisena sillä luotan täysin ohjaajani kykyyn arvioida työni laadukkuutta. Tiedeyhteisössä 
näen työni avaavan tiettyjä alueita lisätutkimukselle ja tarjoavan uutta tietoa. Väitöskirjan tekijänä olen itsenäinen tutkija ja vertainen muiden kanssa, mutta toisaalta opiskelija, jolla on halu ja oikeus olla tietämättä ja kysyä ja saada vastauksia ja ohjausta."

Voimauttava 1

Toisaalta enemmistö, 56 prosenttia, tohtoriopiskelijoista kuvasi suhdettaan tiedeyhteisöön uupumisen ja syrjäytymisen kokemusten valossa ja näki tiedeyhteisönsä kuormitustekijänä. He raportoivat toivovansa suhteensa tiedeyhteisöön olevan erilainen. Opiskelijat kuvasivat ulkopuolisuuden kokemuksen väitöskirjatutkimuksen ja edelleen oman kehittymisen kannalta haitallisena tekijänä. Opiskelijoiden kuvauksille tyypillistä oli myös kokemus siitä, että muu tiedeyhteisö ei arvosta heitä. Vastauksista heijastui kokemus siitä, että tohtoriopiskelijoita ylipäänsä ei pidetty merkityksellisinä tai arvokkaina tiedeyhteisön toiminnan kannalta. Samanaikaisesti he kokivat tekevänsä suurimman osan käytännön työstä ja kontribuoivansa eniten esimerkiksi tieteellisissä julkaisuissa. Kuormittavan kokemuksen raportoitiin tyypillisesti olevan yhteydessä päinvastaisiin syihin kuin voimauttavan kokemuksen. Se yhdistettiin muun muassa ulkopuolisuuden, merkityksettömyyden ja arvottomuuden kokemukseen, oman tilanteen monimutkaisuuteen, sekä nykyhetken että tulevaisuuden työtilanteeseen liittyvään epävarmuuteen ja tuen puutteeseen.

"Mitä siinä erityisesti näkee? Sitä on vaan toisille haitaksi. Ei sitä voi paljon itselleen roolia ottaa, jos on suorastaan toisen armoilla. Teet työtä yksinään ilman että kukaan auttaa mitenkään. Pysy vaan yksinäsi ja hiljaa äläkä kritikoi systeemiä, siitä on vaan huonot seuraukset!"

Kuormittava 1

Koetun osallisuuden ja hyvinvoinnin yhteys toisiinsa

Tutkimustulokset osoittivat myös, että opiskelijoiden osallisuuden kokemus oli yhteydessä koettuun hyvinvointiin. Ne tohtoriopiskelijat, jotka kokivat itsensä osalliseksi tiedeyhteisöön raportoivat useammin voimautumisen ja inspiraation kokemuksia, kun ne, jotka kokivat itsensä ulkopuoliseksi tai roolinsa jäsentymättömäksi tai risti- riitaiseksi. Samanaikaisesti 29 prosenttia myös niistä opiskelijoista, jotka kokivat osallisuutta suhteessa tiedeyhteisöön, kertoivat kuormittumisen ja pettymyksen kokemuksista. (Ks. Taulukko 2.) Yhteys näiden kokemusten välillä oli tilastollisesti erittäin merkitsevä $\left(x^{2}=194, \mathrm{df}=2, \mathrm{p}=.000\right)$.

Tiedeyhteisön merkitys oman väitöskirjaprosessin etenemisen näkökulmasta

Kokemus osallisuudesta ja tiedeyhteisön voimauttavuudesta oli yhteydessä siihen, olivatko opiskelijat jossain vaiheessa omaa väitöskirjaprosessiaan harkinneet opintojensa keskeyttämistä (ks. Taulukko 3). Ne opiskelijat, jotka kokivat kuuluvansa omaan tiedeyhteisöön, ja edelleen ne, jotka kokivat tiedeyhteisön voimauttavaksi tekijäksi omassa väitöskirjaprosessissaan, olivat harvemmin harkinneet opintojen keskeyttämistä.

Lisäksi osallisuuden kokemuksella ja edelleen väitöskirjaprosessin näkökulmasta voimauttavaksi koetulla suhteella tiedeyhteisöön oli positiivinen yhteys myös opintojen kestoon (ks. Taulukko 4). Tulokset osoittivat, että niiden tohtoriopiskelijoiden opinnot olivat harvemmin pitkittyneet (kestäneet yli 10 vuotta), jotka kokivat itsensä osaksi tiedeyhteisöä ja toisaalta tiedeyhteisön oman väitöskirjaprosessinsa näkökulmasta voimauttavana tekijänä.

Taustatekijöiden yhteys osallisuuden ja hyvinvoinnin kokemuksiin

Tohtoriopiskelijoiden kokemukset osallisuudesta ja hyvinvoinnista tiedeyhteisössään olivat hyvin samankaltaisia kaikissa kolmessa yliopistossa eikä tilastollisesti merkitsevää yhteyttä näiden väliltä ollut löydettävissä. Myöskään sukupuolella ei ollut tilastollisesti merkitsevää yhteyttä osallisuuden ja hyvinvoinnin kokemuksiin.

Ryhmässä työskentely oli yhteydessä koettuun osallisuuteen ja hyvinvointiin. Tulokset osoittivat, että se tekikö henkilö väitöskirjatutkimustaan osana tutkimusryhmää, yksin vai sekä että oli yhteydessä sekä koettuun hyvinvointiin että osallisuuden kokemukseen tiedeyhteisössä. Taulukosta 5 nähdään, että ne opiskelijat, jotka työskentelivät ainakin osittain osana jotakin tutkimusryhmää, kokivat muita useammin itsensä osalliseksi sekä tiedeyhteisön inspiroivaksi ja voimauttavaksi tekijäksi. Samanaikaisesti melko suuri osa niistä, jotka työskentelivät osana tutkimusryhmää, kokivat tästä huolimatta ulkopuolisuutta ja kuormittumis- 
TAULUKKO 2: Koettu hyvinvointi suhteessa osallisuudenkokemukseen

\begin{tabular}{lcccccc} 
& \multicolumn{2}{c}{ Voimauttava kokemus } & \multicolumn{2}{c}{ Kuormittava kokemus } & \multicolumn{2}{c}{ Yhteensä } \\
& \multicolumn{1}{c}{ km } & $\%$ & $1 \mathrm{~km}$ & $\%$ & $1 \mathrm{~km}$ & $\%$ \\
\hline Osa tiedeyhteisöä & 199 & 71 & 80 & 29 & 279 & 100 \\
Ulkopuolinen & 14 & 8 & 158 & 92 & 172 & 100 \\
Jäsentymätön/ & & & & & & \\
Ristiriitainen käsitys & 21 & 22 & 75 & 78 & 96 & 100 \\
Yhteensä & 234 & 43 & 313 & 57 & 547 & 100 \\
\hline
\end{tabular}

TAULUKKO 3: Kokemus osallisuudesta ja hyvinvoinnista suhteessa opintojen keskeyttämisen harkintaan

\begin{tabular}{|c|c|c|c|c|c|c|}
\hline & \multicolumn{2}{|c|}{$\begin{array}{l}\text { Oli harkinnut } \\
\text { keskeyttämistä }\end{array}$} & \multicolumn{2}{|c|}{$\begin{array}{l}\text { Ei ollut harkinnut } \\
\text { keskeyttämistä }\end{array}$} & \multicolumn{2}{|c|}{ Yhteensä } \\
\hline & $1 \mathrm{~km}$ & $\%$ & $1 \mathrm{~km}$ & $\%$ & $\mathrm{~km}$ & $\%$ \\
\hline \multicolumn{7}{|l|}{ Osallisuuden kokemus* } \\
\hline Osa tiedeyhteisöä & 183 & 41 & 268 & 59 & 451 & 100 \\
\hline Ulkopuolinen & 126 & 53 & 114 & 47 & 240 & 100 \\
\hline Jäsentymätön/ristiriitainen & 65 & 46 & 76 & 54 & 141 & 100 \\
\hline YHTEENSÄ & 374 & 45 & 458 & 55 & 832 & 100 \\
\hline \multicolumn{7}{|l|}{ Kokemus hyvinvoinnista* } \\
\hline Tiedeyhteisö voimauttava tekijä & 88 & 33 & 179 & 67 & 267 & 100 \\
\hline Tiedeyhteisö kuormitustekijä & 199 & 59 & 139 & 41 & 338 & 100 \\
\hline YHTEENSÄ & 287 & 48 & 318 & 52 & 605 & 100 \\
\hline
\end{tabular}

TAULUKKO 4: Kokemus osallisuudesta ja hyvinvoinnista suhteessa opintojen pitkittymiseen

\begin{tabular}{llll}
$\begin{array}{l}\text { Opinnot } \\
\text { pitkittyneet }\end{array}$ & $\begin{array}{l}\text { Opinnot eivät } \\
\text { pitkittyneet }\end{array}$ & \multicolumn{2}{c}{ Yhteensä } \\
$\mathrm{lkm} \%$ & $\mathrm{lkm} \quad \%$ & $1 \mathrm{~km}$ & $\%$
\end{tabular}

Osallisuuden kokemus*

Osa tiedeyhteisöä

$\begin{array}{rrrrrr}44 & 11 & 360 & 89 & 404 & 100 \\ 50 & 26 & 141 & 74 & 191 & 100 \\ 10 & 9 & 106 & 91 & 116 & 100 \\ 104 & 15 & 607 & 85 & 711 & 100\end{array}$

Kokemus hyvinvoinnista**

\begin{tabular}{lcccccc} 
& \multicolumn{2}{c}{ Voimauttava kokemus } & \multicolumn{2}{c}{ Kuormittava kokemus } & \multicolumn{2}{c}{ Yhteensä } \\
& $\mathrm{lkm}$ & $\%$ & $\mathrm{~km}$ & $\%$ & \multicolumn{1}{c}{$\mathrm{km}$} & $\%$ \\
\hline Osa tiedeyhteisöä & 199 & 71 & 80 & 29 & 279 & 100 \\
Ulkopuolinen & 14 & 8 & 158 & 92 & 172 & 100 \\
Jäsentymätön/ & & & & & & \\
Ristiriitainen käsitys & 21 & 22 & 75 & 78 & 96 & 100 \\
Yhteensä & 234 & 43 & 313 & 57 & 547 & 100 \\
\hline
\end{tabular}

$\begin{array}{lccccc}22 & 9 & 223 & 91 & 245 & 100 \\ 59 & 22 & 212 & 78 & 271 & 100 \\ 81 & 16 & 435 & 84 & 516 & 100\end{array}$

* Yhteys opintojen pitkittymiseen tilastollisesti erittäin merkitsevä $\left(x^{2}=28,274, d f=2, p=.000\right)$.

** Yhteys opintojen pitkittymiseen tilastollisesti erittäin merkitsevä $\left(x^{2}=15,910, d f=1, p=.000\right)$. 
TAULUKKO 5: Kokemus hyvinvoinnista ja osallisuudesta suhteessa tutkimusryhmässä työskentelyyn *

\begin{tabular}{|c|c|c|c|c|c|c|c|c|}
\hline & Osal & & Ulk & dolinen & $\begin{array}{l}\text { Jäse } \\
\text { ristir }\end{array}$ & $\begin{array}{l}\text { nätön/ } \\
\text { nen }\end{array}$ & Yht & \\
\hline & $\mathrm{km}$ & $\%$ & $1 \mathrm{~km}$ & $\%$ & $\mathrm{~km}$ & $\%$ & $\mathrm{lkm}$ & $\%$ \\
\hline Yksin & 304 & 48 & 220 & 35 & 111 & 17 & 635 & 100 \\
\hline Ryhmässä & 75 & 80 & 5 & 5 & 14 & 15 & 94 & 100 \\
\hline Sekä että & 61 & 73 & 9 & 11 & 14 & 16 & 84 & 100 \\
\hline YHTEENSÄ & 440 & 54 & 234 & 29 & 139 & 17 & 813 & 100 \\
\hline$* *$ & $\begin{array}{l}\text { Tied } \\
\text { voin }\end{array}$ & ttei & kijä & & $\begin{array}{l}\text { Tied } \\
\text { kuor }\end{array}$ & $\begin{array}{l}\text { teisö } \\
\text { Istekijä }\end{array}$ & Yht & \\
\hline & $1 \mathrm{~km}$ & $\%$ & & & $\mathrm{~km}$ & $\%$ & $1 \mathrm{~km}$ & $\%$ \\
\hline Yksin & 181 & 38 & & & 291 & 62 & 472 & 100 \\
\hline Ryhmässä & 39 & 61 & & & 25 & 39 & 64 & 100 \\
\hline Sekä että & 43 & 70 & & & 18 & 30 & 61 & 100 \\
\hline YHTEENSÄ & 263 & 44 & & & 334 & 56 & 597 & 100 \\
\hline
\end{tabular}

* Yhteys ryhmässä/yksin työskentelyyn $\left(x^{2}=56,754, d f=4, p=.000\right)$.

** Yhteys ryhmässä/yksin työskentelyyn $\left(x^{2}=30,938, d f=2, p=.000\right)$.

TAULUKKO 6: Kokemus osallisuudesta suhteessa tieteenalaan

Osallisuuden kokemus*

Osallinen Ulkopuolinen
käsitys

Jäsentymätön Yhteensä

$\mathrm{km}$

$1 \mathrm{~km} \quad \%$

Humanistiset tieteet

196

54
50
42
62

$\begin{array}{rc}107 & 29 \\ 30 & 34 \\ 51 & 38 \\ 38 & 25\end{array}$

29

$\mathrm{km} \quad \%$

$1 \mathrm{~km} \%$

Yhteiskunta- ja kauppatieteet 45

56

96

62

17

365

100

Lääke- ja terveystiede $54 \quad 66$

12

15

16

19

19

100

Yhteensä

447

54

238

29

138

17

823

100

* Yhteys tilastollisesti merkitsevä $\left(x^{2}=21,662, d f=8, p=.006\right)$

ta. Heillä kokemus saattoi johtua siitä, minkälaisten vuorovaikutuskäytänteiden varaan tämän ryhmän toiminta perustui, eikä siitä ettei heillä olisi ollut tutkimusryhmää tukenaan.

Se, mitä tieteenalaa tohtoriopiskelijat edustivat, oli yhteydessä ainoastaan osallisuuden kokemukseen. Taulukosta 6 näemme, että lääke- ja terveystieteen, matemaattis-luonnontieteellisten ja teknillistieteellisten alojen opiskelijat kokivat muita useammin kuuluvansa tiedeyhteisöön. Ulkopuolisimmiksi itsensä suhteessa tiedeyhteisöön kokivat puolestaan käyttäytymistieteellisten alojen tohtoriopiskelijat. Yhteys kokemusten ja tieteenalan välillä oli tilastollisesti merkitsevä. Samanaikaisesti koetulla hyvinvoinnilla ei puolestaan ollut tilastollisesti merkitsevää yhteyttä tieteenalaan, jota opiskelijat edustivat. Opiskelijat siis kokivat tiedeyhteisön useammin kuormitustekijäksi kuin voimautumisen tai inspiraation lähteeksi tieteenalasta riippumatta.

\section{Tutkimuksen luotettavuuden tarkastelu}

Olemme tavoittaneet kyselyllämme suuren joukon eri alojen tohtoriopiskelijoita kolmesta suuresta suomalaisesta yliopistosta. Aineiston laajuus voidaankin nähdä yhtenä tutkimuksemme vahvuute- 
na. Eri alojen opiskelijoiden kokemukset omasta hyvinvoinnistaan ja osallisuudestaan tiedeyhteisön jäseninä tarjoavat laajan kuvan ilmiöstä. Vaikka aineistomme ei vastaajien lukumäärässä yllä aivan samalle tasolle kuin Hiltusen ja Pasasen vuonna 2006 raportoima selvitys tohtoriopiskelijoiden kokemuksista, voidaan tämän tutkimuksen vahvuutena nähdä avointen kysymysten avulla esiin saatu opiskelijoiden oma ääni.

Tavoittamamme otos tohtoriopiskelijoita edustaa sukupuolijakaumaltaan ja iältään suomalaista tohtoriopiskelijoiden perusjoukkoa melko hyvin. Otoksessa on myös edustettuna erilaiset väitöskirjatekijät: yksin väitöskirjaa tekevät, ryhmässä työskentelevät, täysipäiväisesti ja osa-aikaisesti tutkimusta tekevät sekä eri-ikäiset opiskelijat. Aineistossa on hieman yliedustettuna ne tohtoriopiskelijat, jotka olivat oman arvionsa mukaan väitöskirjaprosessinsa viimeisessä kolmanneksessa (vrt. Hiltunen \& Pasanen, 2006). Tämä saattaa johtua siitä, että he ovat kokeneet pystyvänsä tarkastelemaan väitöskirjaprosessiaan laajasti useamman vuoden kokemuksen perusteella. Vastaamatta jättäminen ja melko alhaisiksi jääneet vastausprosentit saattavat puolestaan selittyä osin sillä, että Helsingin ja Oulun yliopistoissa kysely lähetettiin kaikille tohtoriopiskelijoille eikä ainoastaan läsnä oleville. Näin ollen listalla on saattanut olla merkittävä määrä henkilöitä, jotka eivät enää tee aktiivisesti tutkimustaan, mutta jotka eivät myöskään ole virallisesti jatko-opinto-oikeudestaan luopuneet.

Tutkimuksen luotettavuutta pyrittiin lisäämään analyysitapoja trianguloimalla. Laadullisen analyysin luotettavuutta pyrittiin edelleen lisäämään sillä, että analyysikriteerit validoitiin jokaisen analyysikierroksen jälkeen tutkimusryhmän sisällä (esim. Miles \& Huberman 1994; Yin 1994). Tulosten face-validiteettia on testattu erilaisissa tohtoriopiskelijoiden pedagogisissa koulutuksissa, jossa osanottajilla on ollut mahdollisuus arvioida tuloksia ja niiden vastaavuutta todellisuuden kanssa yhdessä tutkijoiden kanssa (esim. Creswell 2003; Bryman 2004).

Yhtenä tutkimuksen rajoitteena voidaan nähdä se, että kysyttäessä opintojen keskeyttämisen harkitsemisesta ja muodostaessamme muuttujan opintojen pitkittymisestä, emme ole voineet ottaa huomioon muun elämän vaikutusta. Saattaa olla, että osan syyt keskeyttämisen harkitsemiselle eivät ole liittyneet väitöskirjaprosessin tekemiseen, vaan esimerkiksi perhetilanteisiin. Sama rajoite koskee opintojen pitkittymisen tarkastelua.

\section{Yhteenveto}

Tiedeyhteisöjen käytännöt näyttävät toimivan paitsi oppimisen ensisijaisena kontekstina; myös keskeisenä hyvinvoinnin ja motivaation rakentumisen ympäristönä. Tuloksemme viittaavat siihen, että tohtoriopiskelijat kokevat oman osallisuutensa tiedeyhteisössä hyvin eri tavoin. Huolestuttavan suuri osa, noin kolmannes, tutkimukseen osallistuneista tohtoriopiskelijoista koki itsensä täysin ulkopuoliseksi suhteessa tiedeyhteisöön. Hiltusen ja Pasasen (2006) tulosten mukaan lähes 70 prosenttia tohtoriopiskelijoista koki itsensä hyväksytyksi jäseneksi tiedeyhteisössä. Myös meidän tulosten mukaan melko suuri osa koki itsensä osalliseksi, mutta tulosten mukaan pelkkää osallisuuden kokemusta tärkeämpää oli koettu osallisuuden laatu. Yli puolet opiskelijoista kokikin tiedeyhteisönsä kuormittavana ja uuvuttavana tekijänä. Tulosten valossa näytti edelleen siltä, että niin osallisuuden kokemukset olivat yhteydessä koettuun hyvinvointiin. Opiskelijoiden jaksamiseen liittyvät saadut tulokset ovat linjassa aiempien tohtoriopiskelijoiden hyvinvointia tarkastelevien tutkimusten kanssa, jotka ovat osoittaneet tohtoriopiskelijoiden olevan melko uupuneita ja stressaantuneita opinnoissaan (esim. Kurtz-Costes, Helmke \& Ülkü-Steiner 2006; Hiltunen \& Pasanen, 206).

Opiskelijoiden kokemukset näyttävät myös olevan yhteydessä opintojen etenemiseen. Oma osallisuuden kokemus ja tiedeyhteisön kokeminen voimauttavana tekijänä näyttivät edistävän opintoja, kun taas ulkopuolisuuden tunne ja tiedeyhteisön kokeminen kuormitustekijänä oli yhteydessä ongelmiin väitöskirjaprosessissa. Tulosten valossa vaikuttaakin siltä, että kokemus osallisuudesta ja voimautumisesta toimi mahdollisesti suojaavana tekijänä opintojen keskeyttämistä tai pitkittymistä vastaan.

Toisin kuin aiempi tutkimus on osoittanut, sukupuolella ei näyttänyt tämän tutkimuksen valossa olevan yhteyttä opiskelijoiden koettuun osallisuuteen ja hyvinvointiin tiedeyhteisössä. Linjassa aiemman tutkimuksen kanssa puolestaan oli se, että kokemukset olivat yhteydessä siihen, työskentelikö opiskelija osana tutkimusryhmää vai ei. Tieteenala sen sijaan oli yhteydessä osallisuuden kokemukseen, mutta ei koettuun hyvinvointiin. (vrt. Hiltunen ja Pasanen, 2006). 


\section{Pohdinta}

Hyvinvoinnin kokemus näyttää tieteellisessä jatkokoulutuksessa kytkeytyvän osallisuuden kokemuksiin. Näin ollen voidaan ajatella olevan merkittävää, että nuorilla tutkijoilla olisi mahdollisuus työskennellä osana yhteisöä.

Vaikuttaa kuitenkin siltä, että pelkkä tutkimusryhmään kuuluminen ei ole oikotie onneen. Olennaisempaa on tarkastella vuorovaikutuksen ja osallisuuden laatua. Tulosten perusteella kehittämisen paikkoja löytyy kaikkien tieteenalojen tohtorikoulutuskonteksteista. Hyvinvoinnin ja opintojen etenemisen yhteys viittaa siihen, että tohtoriopiskelijan hyvinvointi ei ole tieteellisten jatko-opintojen sivutuote tai ylimääräinen tekijä prosessissa, vaan yhteydessä myös tulokseen; väitöskirjan valmistumiseen ja asiantuntijuuden oppimiseen. Kokemus omasta osaamisesta ja pätevyydestä syntyy silloin, kun tohtoriopiskelijalla on mahdollisuus saada palautetta toiminnastaan yhteisön jäsenenä. Näyttää siltä, että tieteellisen jatkokoulutuksen tavoitteiden ja kehittämisen kannalta olisi tärkeää pohtia, kuinka tohtorinkoulutukseen liittyviä käytäntöjä voidaan rakentaa niin, että ne tukevat tohtoriopiskelijoiden osallisuuden ja edelleen hyvinvointia tuottavan mielekkään väitöskirjaprosessin rakentumista.

Tiedeyhteisön tarjoama oppimisympäristö on keskeinen tutkijaksi ja asiantuntijaksi kasvamisen konteksti ja siihen kuulumisella ja siinä toimimisella on merkittävä vaikutus ehyen ja mielekkään väitöskirjaprosessin rakentumisessa. Väitöskirjaprosessin onnistumisen näkökulmasta jäseneksi ottamisen ja sosiaalisen integraation tulisikin tietoisesti huolehtia osana väitöskirjatutkimuksen teon kokonaisuutta. Opiskelijan osallisuuden kehittymistä voidaan tukea pyrkimällä rakentamaan avoimia, hyväntahtoisia ja inspiroivia oppimisympäristöjä, jotka mahdollistavat työskentelyn yhdessä muiden yhteisön jäsenten kanssa. (esim. John-Steiner 2000; Mandel, Gruber \& Renkel 1996; Moss, G. \& Kubacki 2007; Rothe jne. 2007). Tiedeyhteisöiden haasteena on tietoisemmin pohtia keinoja miten nuoria tutkijoita "kuljetetaan" yhteisön reunamilta hiljalleen kohti ydintä ja täyttä jäsenyyttä. Tällaisia oppimisympäristöjä ja prosesseja ei voida rakentaa erikseen muusta tiedeyhteisön toiminnasta; tieteellisen jatkokoulutuksen tulisi pikemminkin kietoutua tieteen tekemisen arjen kanssa ja toimia osana tiedettä edistävää yhteisöä.
Pelkkä henkilökohtainen ohjaus, hyväkään, ei siis välttämättä tarjoa kaikkea sitä tukea, jota oman alansa asiantuntijaksi kasvamassa oleva tohtoriopiskelija tarvitsee. Tohtoriopiskelijan ohjausympäristöä voidaankin tarkastella systeemisenä kokonaisuutena, jossa erilaisilla ohjauksen tasoilla on oma merkityksensä (Nummenmaa \& Soini 2009). Ohjauksen kokonaisuudessa esimerkiksi erilaiset vertaisryhmät muodostavat yhden tärkeän elementin tohtoriopiskelijan omassa prosessissa ja ne tulisikin tunnistaa ohjauksellisena voimavarana (Boud \& Lee 2005; Soini 2008). Esimerkiksi tieteellistä kirjoittamista on opetettu vertaisryhmissä, yhteistoiminnallisesti (Lonka 2003). Tällöin vertaisvuorovaikutus mahdollistaa oppimista tukevilla lähikehitysvyöhykkeillä työskentelyn (ks. Vygotsky 1978).

Tieteelliseksi asiantuntijaksi kasvaminen ei ole vain tietojen ja taitojen karttumista, vaan se on myös identiteetin rakentamista. Tässä identiteettityön ohjauksessa keskeisintä on autonomian, itsenäisyyden lisääntyminen. Se muodostaa ohjauksen paradoksin: tohtoriopiskelijan ohjaamisen kohti yhä itsenäisempää, ohjauksesta riippumatonta toimintaa. Vertaisryhmissä toimiminen voi olla silta itsenäisempään rooliin. Vertaisryhmät toimivat myös hyvinä oman osaamisen testaamisen kenttinä.

Tässä artikkelissa olemme tarkastelleet tohtoriopiskelijoiden kokemaa hyvinvointia ja osallisuutta tiedeyhteisöissä. Tulokset herättävät myös kysymään, miten on näiden asioiden laita tiedeyhteisöissä, laitoksilla, yksiköissä ja tutkimusryhmissä ylipäätään. Osallistavan ja tukevan oppimisympäristön tarjoaminen tohtoriopiskelijalle edellyttää sitä, että yhteisön jäsenet näkevät toimintaan osallistumisen merkittävänä väylänä tieteelliseksi asiantuntijaksi kasvussa. Lisäksi edellytyksenä on, että yhteisössä on luotu käytänteitä osallisuuden tukemiseksi. Nämä vaativat yhteisöltä yhteistä merkityksenantoa ja toisaalta merkitysneuvotteluita omasta toiminnastaan.

Tiedeyhteisöjen yhteinen ja avoin keskustelu siitä, miten siellä toimitaan ja voitaisiin toimia erilaisten koulutuksellisten ja tutkimuksellisten tavoitteiden toteutumiseksi, on yliopistojen kiireisessä arjessa haastavaa. Se voi kuitenkin toimia, ei vain jatkokoulutuksen, vaan koko yhteisön toiminnan kehittämisen välineenä ja näin hyödyttää tieteellistä työtä laajemmin. 


\section{LIITE 1.}

Tohtoriopiskelijoiden sukupuolijakaumat koulutusaloittain Helsingin, Tampereen ja Oulun yliopistoissa siltä osin kun tiedot ovat olleet saatavilla (helsinki.fi/tilastot ja tilastokeskuksen vuoden 2008 tilastot).

\begin{tabular}{lll} 
& $\begin{array}{l}\text { Naiset } \\
\%\end{array}$ & $\begin{array}{l}\text { Miehet } \\
\%\end{array}$ \\
\hline $\begin{array}{ll}\text { Helsingin yliopisto } \\
\text { Humanistiset tieteet }\end{array}$ & 66 & 34 \\
Käyttäytymistieteet & 76 & 24 \\
Lääketiede & 71 & 29 \\
Tampereen yliopisto & & \\
Yhteiskuntatieteet & 59 & 41 \\
Kasvatustieteet & 71 & 29 \\
Terveystiede & 85 & 15 \\
Oulun yliopisto & & \\
Humanistiset tieteet & 70 & 30 \\
Kasvatustieteet & 73 & 27 \\
Luonnontieteet & 51 & 49 \\
Lääketiede & 68 & 32 \\
Kauppatieteet & 63 & 27 \\
Teknilliset tieteet & 29 & 71 \\
\hline
\end{tabular}

\section{LIITE 2}

Väitelleiden mediaani-ikä koulutusaloittain Helsingin, Tampereen ja Oulun yliopistoissa siltä osin kun tiedot ovat olleet saatavilla (Tilastokeskuksen vuoden 2008 tilastot).

Helsingin yliopisto

Humanistinen koulutus

42,4

Kasvatustieteellinen koulutus $\quad 53,1$

Lääketieteellinen koulutus

Tampereen yliopisto

Humanistinen koulutus

42.6

Kasvatustieteellinen koulutus $\quad 47.9$

Lääketieteellinen koulutus

36.8

Oulun yliopisto

Humanistinen koulutus

45.8

Kasvatustieteellinen koulutus

51.9

Lääketieteellinen koulutus

\section{Kiitokset}

Kiitämme lämpimästi Helsingin yliopistoa (projektinumero: 2106008) ja Suomen Akatemiaa (projektinumero: 121207), joiden myöntämin varoin tässä artikkelissa esitelty tutkimus on tehty.

\section{Lähteet}

Appel, M. L. \& Dahlgren, L. G. (2003). Swedish doctoral students' experiences on their journey towards a Ph.D.: obstacles and opportunities inside and outside the academic building. Scandinavian Journal of Educational Research, 47 (1), 89-110.

Bair, C. R. \& Haworth, J. G. (1999). Doctoral student attrition and persistence: A meta-analysis of research. Paper prepared for presentation at the annual meeting of the Association for the study of Higher Education (ASHE). San Antonio, Texas, November 20 ${ }^{\text {th }}, 1999$.

Bauer, M., Abric, J. C., Drozda-Senkowska, E., Lemaire, P., Lorenzi-Cioldi, F, Niedenthal, P., Sanitioso, R. B., Schadron, G., Steiner, D. and Yzerbyt, V. (2003). Doctoral training in the French-speaking countries of Europe: objectives and suggestions for improvement. $\mathrm{Eu}$ ropean Psychologist 8, 9-17.

Becher, T. (1994). The significance of disciplinary differences. Studies in Higher Education, 19 (2), 151-162.

Becher, T. \& Trowler, P. R. (2001). Academic tribes and territories. 2nd ed. The Society for Research into Higher Education and Open University Press.

Biglan, A. (1973). The characteristics of subject matter in different academic areas. Journal of Applied Psychology, 57 (3), 195-203.

Boud, D. \& Lee, A. (2005). 'Peer learning' as pedagogic discourse for research education. Studies in Higher Education, 30 (5), 501-516.

Bryman, A. (2004). Social research methods. 2. Edition. Oxford University Press.

Creswell, J.W. (2003). Research design. Qualitative, quantitative and mixed methods approaches. 2. Edition. Thousand Oaks: Sage.

Delamont, S., Atkinson, P. \& Parry, O. (2000). The doctoral experience: Success and failure in graduate school. London: Falmer Press.

Gardner, S. (2007). 'I heard it through the grapevine": doctoral student socialisation in chemistry and history. Higher Education, 54, 723-740.

Gardner, S. (2008). Fitting the mold of graduate school: A qualitative study of socialization in doctoral education. Innovations in Higher 
Education, 33, 125-138.

Golde, C. M. (2000). Should I stay or should I go? Student descriptions of the doctoral attrition process. The Review of Higher Education, 23 (2), 199-227.

Golde, C. M. (2005). The role of department and discipline in doctoral student attrition: Lessons from four departments. The Journal of Higher Education, 76 (6), 669-700.

Hasrati, M. (2005). Legitimate peripheral participation and supervising Ph.D. students. Studies in Higher Education, 30 (5), 557-570.

Hiltunen, K. \& Pasanen, H-M. (2006). Tulevat tohtorit. Jatko-opiskelijoiden kokemukset ja arviot tohtorinkoulutuksesta 2005. Opetusministeriön julkaisuja 2006:48.

Hoskins, C. M. \& Goldberg, A. D. (2005). Doctoral student persistence in counselor education programs: Student-Program Match. Counselor Education and Supervision, 44, 175- 188.

John-Steiner, V. (2000). Creative collaboration. New York: Oxford University Press.

Kurtz-Costes, B., Helmke, A. L. \& Ülkü-Steiner, B. (2006). Gender and doctoral studies: the perceptions of Ph.D. students in an American university. Gender \& Education, 18 (2), 137155.

Lonka, K. (2003). How to help doctoral students' to finish their thesis? Teoksessa: Rijlaarsdam, G., Björk, L., Bräuer, G., Rienecker, L. \& Stray Jorgensen, P. (Toim.) Studies in writing, teaching academic writing in European higher education, Vol. 12. Kluwer Academic Publisher: Netherlands, 113-131.

Lonka, K., Sharafi, P., Karlgren, K., Masiello I., Nieminen, J., Birgegård, G., \& Josephson, A. (2008). Development of MED NORD - A tool for measuring medical students' well-being and study orientations. Medical Teacher, 30, 72-79.

Luker, K. A. \& Orr, J. (1992). Health visiting: towards community health nursing. Oxford: Blackwell Science.

Mandel, H., Gruber, H. \& Renkel, A. (1996). Communities of practice toward expertise: social foundation of university instruction. Teoksessa: Baltes, P. \& Staudinger, U. (toim.), Interactive minds. Life-span perspectives on the social foundation of cognition. Cambrid- ge: Cambridge University Press.

McAlpine, L., Jazvak-Martek, M. \& Hopwood, N. (2008). Doctoral student experience: Activities and difficulties affecting identity development. International Journal of Graduate Education, 1 (2).

McAlpine, L., \& Amundsen, C. (2009). Identity and agency: Pleasures and collegiality among the challenges of the doctoral journey. Studies in Continuing Education, 31 (2), 107-123

Miles, M.B. \& Huberman, A.M. (1994). Qualitative data analysis. An expanded sourcebook. 2nd edition. Thousand Oaks: Sage.

Moss, G. \& Kubacki (2007). Researchers in higher education: neglected focus of study? Journal of Further and Higher Education, 31(3), 297-310.

Nettles, M. T. \& Millet, C. M. (2006). Three magic letters: Getting to Ph.D. Baltimore: the John Hopkins University Press.

Nummenmaa, A. R. \& Pyhältö, K. (2009). Tohtorikoulutus systeemisenä kokonaisuutena. Teoksessa: Nummenmaa, A. R., Pyhältö, K. \& Soini, T. (toim.) Hyvä tohtori! Tohtorikoulutuksen rakenteita ja prosesseja. Tampere University Press: Tampere, 22-37.

Nummenmaa, A. R. \& Soini, H. (2009). Akateeminen ohjaus tiedeyhteisössä. Kasvatus, 5, 432-442.

Oost, H. \& Sonneveld, H (2004). Completion rate and duration of Ph.D studies at Dutch research schools. Utrecht/Amsterdam: IVLOS/ ASSR.

Pyhältö, K., Soini, T., \& Pietarinen, J. (2009) (painossa) Pupils' pedagogical well-being in comprehensive school - Significant positive and negative school experiences of Finnish nine graders'. The European Journal of Psychology of Education.

Pyhältö, K., Toom, A., Stubb, J. \& Lonka, K. (2009). Pitfalls and gaps within the Ph.D. process-Perceived problems and experienced well-being among Ph.D. students. Paper presented at the Annual Meeting of American Educational Research Association: Disciplined Inquiry: Education Research in the Circle of Knowledge. San Diego, California, April $13^{\text {th }}-17^{\text {th }}, 2009$.

Pyhältö, K., Stubb, J. \& Lonka, K. (2009). Deve- 
loping scholarly communities as learning environments for doctoral students. International Journal for Academic Development, 14 (3), 221-232.

Pyhältö, K. \& Soini, T. (2009). Tohtoriopiskelijasta tieteelliseksi asiantuntijaksi. Teoksessa: Nummenmaa, A. R., Pyhältö, K. \& Soini, T. (toim.) Hyvä Tohtori! Tohtorikoulutuksen rakenteita ja prosesseja. Tampere University Press: Tampere, 137-162.

Rothe, W-M, Ardenghi, D, Boyer, L., Chen, P. Emad, G. Hsu, P-L., Jaime, B. Kim, M., Ardenghi, L. Reis G., Stith, I \& van Eijck, M. (2007). Being, becoming, and belonging. Life in an International Research Group. Teoksessa: Rithchie, S. M. (toim.) Research Collaboration: Relationships and Praxis. Sense Publisher, 1-25.

Ryan, R. \& Deci, E. (2000). Self-Determination Theory and the Facilitation of Intrinsic Motivation, Social Development, and Well-Being. American Psychologist, 55 (1), 68-78.

Ryan, R. \& Deci, E. (2001). On happiness and human potentials: A review of research on hedonic and eudaimonic well-being. Annu. Rev. Psychol. 52, 141-166.

Ryan, R. \& Deci, E. (2008). Facilitating Optimal Motivation and Psychological Well-Being Across Life's Domains. Canadian Psychology, 49 (1), 14-23.

Soini, H. (2008). Vertaisohjaus akateemisen ohjauksen työtapana. Teoksessa: Nummenmaa, A. R., Pyhältö, K. \& Soini, T. (toim.) Hyvä Tohtori! Tohtorikoulutuksen rakenteita ja prosesseja. Tampere University Press: Tampere, 127-137.

Stubb, J., Pyhältö, K. \& Lonka, K. (2009). Doctoral students as active agents in scholarly communities? Esitetty EARLI 2009 -konferenssissa (European Association for Research on Learning and Instruction). Amsterdamissa, Hollannissa, 25.-29. Elokuuta.

Styles, I. \& Radloff, A. (2001). The Synergistic Thesis: student and supervisor perspectives. Journal of Further and Higher Education, 25 (1), 97-106.

Toews. J. A., Lockyer, J. M., Dobson, D. J. and Brownell, A. K. (1993). Stress among residents, medical students and graduate science (M.Sc./Ph.D) students. Academic Medici- ne, 68, 46-48.

Vehviläinen, S., Pyhältö, K., Lindblom-Ylänne, S., Löftström, E., Nevgi, A. \& Kaartinen-Koutaniemi, M. (2009). Tieteellisten työprosessien ohjaus. Teoksessa: Lindblom-Ylänne, S. \& Nevgi, A. (toim.) Yliopisto-opettajan käsikirja. WSOYPro: Helsinki, 334-372.

Vermunt, J. D. \& Verloop, N. (1999). Congruence and friction between learning and teaching. Learning and Instruction, 9 (3) 257-280.

Vygotsky, L. S. (1978). Mind in society. The development of higher psychological processes. Harvard University Press. Cambridge, Massachussets.

Wenger, E. (1999). Communities of learning. Learning, meaning, and identity. Cambridge: Cambridge University Press.

Wright, T. (2003). Postgraduate research students: people in context? British Journal of Guidance and Counselling, 31 (2), 209-227.

Yin, R.K. (1994). Case study research. Design and methods. 2. Edition. Thousand Oaks: Sage.

Ylijoki, O-H. (1998). Akateemiset heimokulttuurit ja noviisien sosialisaatio. Vastapaino.

Artikkeli saapui toimitukseen 4.5.2009. Se hyväksyttiin julkaistavaksi toimituskunnan kokouksessa 30.11.2009. 